\title{
ATTRIBUTIONS TO ACADEMIC SUCCESS AND FAILURE AND THE STRATEGIES FOR DEALING WITH THE EXAMINATION SITUATION AS PREDICTORS OF ACADEMIC SUCCESS
}

\author{
UDC 159.947.5:371.26
}

\author{
Gordana Đigić ${ }^{1}$, Milica Zdravković \\ ${ }^{1}$ University of Niš, Faculty of Philosophy, Department of Psychology \\ ${ }^{2}$ School for Primary Music Education "Miodrag Vasiljević", Bor, Serbia
}

\begin{abstract}
The study was aimed at investigating students' attributions to academic success/failure and the strategies for dealing with the examination situation as predictors of academic success. Students' attributions to academic success/failure by internal/external and stable/unstable causes were examined by the Scale of Attributions to Academic Success and Failure. The strategies for dealing with the examination situation (focusing on the problem, focusing on emotions, imagination/distraction, seeking help in the examination situation) were examined by the Scale of Dealing with Examination Situation. The results obtained on the sample of second grade grammar school students $(N=204)$ show that students' attributions to academic success/failure and the strategies of dealing with the examination situation explain a significant percent of variance in academic success $\left(R^{2}=.210, p=.000\right)$. The most important particular predictor is the strategy of dealing with the examination situation by focusing on the problem ( $\beta=.244, p=.005)$. Students' attributions to failure are more important predictors of academic success than attributions of success. Differences between boys and girls in the patterns of particular predictors of academic success were found. The results point out that it is important to support constructive students' styles of attributions to academic success/failure and the strategies for dealing with examination situations.
\end{abstract}

Key words: students, academic success, students' attributions to academic success and failure, dealing with the examination situation

\section{INTRODUCTION}

Academic success, which is usually expressed in school grades (Božin 2003), is most often taken as a basic indicator of students' educational achievement (Gadžić and Milojević 2009), despite numerous admonitions that could be addressed to the quality of

Received August 9, 2019 / Accepted September 11, 2019

Corresponding author: Gordana Đigić

University of Niš, Faculty of Philosophy, Ćirila i Metodija 2, 18000 Niš, Serbia

E-mail: gordana.djigic@ filfak.ni.ac.rs 
school assessment. Taking into account that the quality of knowledge, skills and attitudes the student builds during schooling determine the future of each individual student and society as a whole (Baucal, Pavlović-Babić, Gvozden and Plut 2006), and that academic success is accepted as a measure of achievement of expected educational goals, it is easy to conclude that students' academic success has great importance. In addition, academic success or failure causes different emotional experiences among students (Vulić-Prtorić and Lončarević 2016), affecting their self-esteem. For these reasons, investigating factors of school performance is worthwhile because it could point to appropriate support to students in achieving the best possible success.

Academic success can be viewed as the result of students' behavior during the learning process and in a test situation which depends partly on the causes that a student attributes to his/her success or failure, as well as on his/her readiness to successfully face the anxiety related to exposure to evaluation. This study is concerned with the connection between school success a students' attributions to academic success or failure and their strategies for dealing with the examination situation.

Attribution theories (Malle 2011) are a convenient framework for understanding students' behavior oriented towards school achievement. Weiner's attribution theory (Weiner 1972, 1985) deals with the causes that students attribute to their results in the achievement situation. When a student interprets a particular result as a success or failure, he/she links it with perceived causes that do not have to be realistic causes of achievement (Bugan, Bajs and Stamać 2001). The consequences of these attributions can be psychological-cognitive and emotional (expectation of success in the next situation and the experience of selfefficacy or the fear of failure and lower self-esteem) and behavioral (persistence and further effort investment or abandonment) (Kodžopeljić and Pekić 2017; Schunk, Pintrich and Meece 2013). Weiner (1985) also points out the consequences of different attributions. The causes by which students explain their success or failure (Table 1) differ in terms of their locus, stability and volitional controllability. Depending on these characteristics of the cause, students can experience various emotions, such as anger, guilt, pleasure, pride, shame, sadness, or helplessness. Also, depending on the attributed causes, students build different expectations about success in future situations, which determines their further engagement oriented towards achievement.

Table 1 Causes of success and failure classified by locus, controllability and stability (Weiner 1979)

\begin{tabular}{lcccc}
\hline \multirow{2}{*}{ Controllability } & \multicolumn{2}{c}{ Internal } & \multicolumn{2}{c}{ External } \\
\cline { 2 - 5 } Uncontrollable & Stable & Unstable & Stable & Unstable \\
Controllable & Ability & Mood & Tusk difficulty & Luck \\
\hline & Typical effort & Immediate effort & Teacher's bias & $\begin{array}{c}\text { Unusual help } \\
\text { from others }\end{array}$ \\
\hline
\end{tabular}

Attributions are not universal. They can vary in different areas, depending on age, culture, gender, as well as on whether an individual evaluates his/her own or others' behavior (Ilić 2017; Kodžopeljić and Pekić 2017). For example, younger students consider effort as the most common cause of success or failure, while at an older age their abilities become more important causes (Lončarić 2014). The attributional schemes could be changed and adjusted on the basis of interaction with experience (Weiner 1985). 
Within the attribution theory, attribution styles are described as relatively consistent and durable ways of interpreting the causes of particular events (Jovanović 2013). Weiner (1979) distinguishes four basic ways in which students explain their success or failure: by their abilities, effort, difficulty of tasks and luck. Depending on how the student usually explains his/her success or failure, the functional and dysfunctional attribution styles could be differentiated (Jovanović 2013). The functional attribution style is the tendency of an individual to attribute his/her abilities and invested effort to successes, and inadequate learning strategies or insufficient effort to failures. An individual with a dysfunctional attribution style explains his/her own successes and failures by external causes (e.g. happiness) or lack of abilities (Alloy, Peterson, Abramson and Seligman 1984). In a situation of repeated failure, such attributions lead to learned helplessness and to school refusal (Gonzalvez et al. 2018). Due to the belief that they cannot control the causes of the outcome, students with a higher level of learned helplessness avoid challenging tasks and easily give up searching for a solution by reason of being afraid of a new failure. On the contrary, students with functional attribution styles use the information about their failure to improve their performance and achieve better future results, and they are less concerned with past failures (Diener and Dweck 1978).

An unavoidable part of the educational process is assessment based on numerous examination situations followed by feedback on how successfully a student has mastered the teaching content. The examination situation is almost indispensably accompanied by the experience of test anxiety, which represents a set of psychological and behavioral reactions related to concerns about a possible failure in this evaluation situation (Zeidner 1998) occurring before, during or after the test situation (Vizek-Vidović, Rijavec, VlahovićŠtetić and Miljković 2003). Test anxiety can be recognized through emotional, physical, cognitive and behavioral manifestations that occur in relation to the examination situation (Cvitković and Wagner-Jakab 2006), such as general tension, fear, an accelerated heartbeat, trembling, a concentration drop, and higher motor activity.

Test anxiety is most often associated with negative effects - achieving a lower performance than expected in relation to an individual's abilities (Birenbaum and Nasser 1994), but also with negative consequences in terms of mental and physical health, selfesteem and self-concept. The negative effect of test anxiety on student achievement can be explained from the point of view of two basic models - the cognitive model and the deficiency model (Mohorić 2008). The cognitive model emphasizes the role of negative automatic thoughts that interfere with the thinking process during learning or a test situation. Namely, two parallel processes take place into the working memory of an anxious individual, competing to obtain as many cognitive resources as possible (Hamilton 1985): the primary process (focused on solving the current problem in the examination situation) and the secondary process (preoccupation with intrusive thoughts). Thus, divided cognitive capacities make it difficult for students to successfully solve the test task, and the result is a lower achievement. The deficiency model (Birenbaum and Nasser 1994) highlights the deficiency in students' cognitive abilities, but also inadequate learning skills. According to this model, students with high test anxiety have difficulties from the very beginning of the learning process: they do not have developed working habits; they have difficulties organizing learned material in meaningful units and the practical application of what they have learned.

Some authors point out that there is also facilitating anxiety that motivates the activity, learning and timely preparation for the exam. It is associated with an increased level of physical tension, but not with the increased concern and the presence of disturbing thoughts 
(Živčić-Bećirević 2003). Such anxiety often involves seeking help, proactivity, and focusing on the problem.

The effect of test anxiety depends to a large extent on students' capacity for emotional regulation in test situations, or the way they deal with test anxiety (Burić, Sorić and Penezić 2011). It is about investing cognitive and behavioral efforts to cope with internal and/or external demands (goals) that are estimated as too difficult for the individual (Lazarus and Folkman 1984, according to Kalebić-Maglica 2006). The basic strategies for coping with stressful situations (Burić et al. 2011) are focus on the problem and focus on emotions. Problem-oriented strategies refer to active confrontation, planning and undertaking actions directed at solving problems, suppressing other competitive activities, seeking information, while emotion-focused strategies include denial, suppression, self-blaming, fantasy, turning to religion, humor, positive thinking and reinterpretation, passivity, expressing emotions, etc. Studies show that problem-oriented strategies are more often and more efficiently used in situations in which people estimate that they have control (Chang 2001), and the outcome is the achievement of one's own goals, while students who focus on emotions move away from task solving, thinking about their emotional experiences and the causes of bad performance. Numerous studies confirm that non-adaptive strategies of dealing with the examination situation (occupation with negative thoughts, errors and negative consequences, self-blaming, feeling of helplessness) are associated with lower success (Cvitković and Wagner-Jakab 2006; McCarthy and Goffin 2005; Stöber 2004; Perkun, Goetz, Titz and Perry 2002; ŽivčićBećirević 2003). Despite these results, based on the research review, Zeidner (1995) concludes that adaptive coping means flexible combined use of both task-oriented and emotion-oriented strategies adjusted to the situation and to the individual.

\section{THE METHOD}

Among the numerous studies dealing with the factors of academic success conducted in Serbia, attribution styles and the strategies for dealing with the test situation are rarely investigated phenomena. Research findings from other countries indicate that these are significant psychological factors of academic success, and this research was conducted with the goal of checking whether this relationship exists among students in Serbia, too. The aim of the study is to determine whether students' attributions to academic success or failure and coping strategies with the test situation contribute to the prediction of academic success of grammar school students. In addition, the research should show whether there are differences between boys and girls in terms of used attributions, strategies for coping with the test situation and academic success, as well as if there exist specific combinations of particular predictors of academic success in subsamples of boys and girls.

The research examines the attribution styles created by crossing the dimension of stability and the dimension of the locus of cause (Weiner 1979) and used by students when they explain the causes of their academic success or failure. The students' attributions are expressed in average scores on subscales of the Scale of Attributions to Academic success and Failure (Lončarić 2014). The Scale consists of eight subscales, each of them including four items. Four subscales examine attribution styles in explaining academic success and four subscales refer to attributions to school failure. The examined attribution styles refer to explaining success or failure by internal stable (abilities), internal unstable (effort, commitment), external stable (teachers, school), and external unstable (luck, 
coincidence) causes. The respondents estimate the extent to which they agree with the given statements on a five-point Likert type scale $(1=\mathrm{I}$ completely disagree, $5=\mathrm{I}$ completely agree). According to the author, all of the subscales have satisfactory reliability (Cronbach $\alpha$ from .72 to .90), and the results obtained in this study are similar (Cronbach $\alpha$ from .73 to .89).

The strategies for dealing with the examination situation refer to the way in which students attempt to overcome emotional reactions during the test situation. The examined strategies imply different types of student orientation in the test situation: focusing on the problem (focusing on the task, respecting previously defined plans), focusing on emotions (feelings of discomfort, panic, tension, helplessness), imagination / distraction (disruptive thoughts, such as self-blaming for not being taught enough, thinking about currently irrelevant things, believing that a miracle will happen) and seeking help (trying to get help from others, for example by copying). These strategies are expressed in average scores on subscales of the Scale of Dealing with the Examination Situation (Sorić 2002). The Scale contains 29 fivepoint Likert type statements. Students assess the extent to which the described method of dealing with the test situation relates to them $(1=$ It does not apply to me at all, $5=$ It fully applies to me). The scale consists of four subscales examining the above-mentioned strategies. According to the data given in the instrument description, all subscales have good reliability (Cronbach $\alpha$ from .75 to .83 ), as well as according to the results of this study (Cronbach $\alpha$ from .72 to .82).

The measure of academic success is the average grade achieved at the end of the previous school year and it is registered using a questionnaire for students, which also includes data on the respondents' gender.

The research was conducted in the autumn of 2018 in four grammar schools from two towns in Serbia, on a convenience sample consisting of 204 second-grade students (boys: $32.8 \%$; girls: $67.2 \%$ ). The instruments were administered to students in groups, during school hours and after obtaining parental consent for the participation of their children in the research. Participation in the research was voluntary and anonymous. The students were also informed about the purpose of the research, they were given instructions on how to complete the questionnaire and it was emphasized that the results will be used exclusively for research purposes.

\section{RESULTS}

Descriptive measures of the tested variables were first determined with the intention of identifying students' attributions to academic success and failure, as well as the strategies for dealing with the test situation, which, based on the stated degree of agreement with the claims in the applied instruments, can be said to be the most expressed among the students from the sample (Table 2).

The degree of students' agreement with the assertions from the scales shows that their success or failure in school is mostly explained by the invested effort, and in the test situation, they are mostly focused on the task. Measures of these attributions of success and failure and this strategy of dealing with the test situation are significantly different from the measures of other examined attributions and strategies (Friedman's test of differences between measures obtained on particular scales: among attributions to success $\chi^{2}=382.22$, df $=3, \mathrm{p}=.000$; among attributions to failures $\chi^{2}=261.24, \mathrm{df}=3, \mathrm{p}=.000$; among the strategies for dealing with test situations $\chi^{2}=261.24, \mathrm{df}=3, \mathrm{p}=.000$ ). The average grade that the 
students from the sample achieved at the end of the previous academic year corresponds to excellent school performance.

Table 2 Descriptive measures of examined variables

\begin{tabular}{lcc}
\hline & M & SD \\
\hline Attributions to Academic Success & 3.90 & 0.87 \\
$\quad$ Internal stable & $\mathbf{4 . 1 4}$ & 0.86 \\
Internal unstable & 1.62 & 0.83 \\
External stable & 2.88 & 0.87 \\
$\quad$ External unstable & & \\
\hline Attributions to School Failure & 1.50 & 0.91 \\
$\quad$ Internal stable & $\mathbf{3 . 4 8}$ & 0.94 \\
Internal unstable & 2.73 & 0.93 \\
External stable & 2.71 & 0.90 \\
External unstable & & \\
\hline Dealing with the Examination Situation & 3.15 & 0.92 \\
Focus on emotions & $\mathbf{3 . 5 9}$ & 0.75 \\
Focus on the problem & 2.99 & 0.85 \\
Fantasy/distraction & 3.20 & 1.08 \\
$\quad$ Seeking help & $\mathbf{4 . 5 8}$ & 0.43 \\
\hline Academic Success & & \\
\hline &
\end{tabular}

Descriptive measures indicate the possibility that the distribution of the tested variables deviates from the normal distribution. The Kolmogorov-Smirnov test confirmed this in all the variables $(\mathrm{p}=.000$ to $\mathrm{p}=.025)$, except in dealing with the test situation by focusing on disturbing thoughts $(\mathrm{p}=.200)$. Therefore, in some subsequent analyses, nonparametric data analysis methods were used, and before the implementation of a standard multiple regression, the assumptions for applying this procedure were verified.

Prior to testing the model of predicting academic success by measures of attributions to academic success and failure and by measures of coping strategies with the test situation, it was determined, based on the Normal Probability Plot (PP) diagram, that the points lie in the right diagonal line from the lower left to the upper right corner of the diagram, which means that there is no large deviation from normality. Also, the scatter plot chart showed that the residuals were approximately rectangularly distributed, that most of the results were piled up in the center, and that no atypical points were identified (as confirmed by a review of Mahalanobis residual distances). After these checks, a standard multiple regression analysis procedure was performed.

The model of prediction of academic success by the measures of all tested attributions to success and failure and the strategies for dealing with the test situation (Table 3) was first tested.

The presented prediction model is statistically significant, and the set of variables included in the model explain $21 \%$ of the variance in academic success. Students' greater focus on the task in the test situation and a more pronounced tendency to explain failure by external unstable causes (to consider failure as a coincidence) give a particular significant contribution to predicting better school performance. 
Table 3 Prediction of academic success by the measures of attributions to success, attributions to failure and the strategies for dealing with the examination situation

\begin{tabular}{|c|c|c|c|c|c|}
\hline \multirow{2}{*}{$\begin{array}{l}\text { Model summary: } \\
\mathrm{R}=.458 ; \mathbf{R}^{2}=. \mathbf{2 1 0} ; \mathrm{F}=4.229 ; \mathbf{p}=. \mathbf{0 0 0}\end{array}$} & \multicolumn{2}{|c|}{$\begin{array}{c}\text { Unstandardized } \\
\text { Coefficients }\end{array}$} & \multirow{2}{*}{$\begin{array}{c}\begin{array}{c}\text { Standardized } \\
\text { Coefficients }\end{array} \\
\text { Beta } \\
\end{array}$} & \multirow[t]{2}{*}{$\mathrm{t}$} & \multirow[t]{2}{*}{ Sig. } \\
\hline & $\mathrm{B}$ & Std. Error & & & \\
\hline \multicolumn{6}{|l|}{ Attributions to Academic Success } \\
\hline Internal stable & .036 & .036 & .072 & .996 & .320 \\
\hline Internal unstable & .070 & .042 & .141 & 1.648 & 101 \\
\hline External stable & -.013 & .041 & -.025 & -.314 & .754 \\
\hline External unstable & -.032 & .038 & -.064 & -.825 & .410 \\
\hline \multicolumn{6}{|l|}{ Attributions to School Failure } \\
\hline Internal stable & -.077 & .040 & -.164 & -1.956 & .052 \\
\hline Internal unstable & -.006 & .032 & -.014 & -.195 & .845 \\
\hline External stable & .040 & .035 & .086 & 1.146 & .253 \\
\hline External unstable & .108 & .037 & $.228^{* * *}$ & 2.949 & .004 \\
\hline \multicolumn{6}{|l|}{ Dealing with the Examination Situation } \\
\hline Focus on emotions & -.008 & .043 & -.018 & -.190 & .850 \\
\hline Focus on the problem & .138 & .049 & $.244^{* *}$ & 2.833 & .005 \\
\hline Fantasy/distraction & -.072 & .045 & -.144 & -1.587 & .114 \\
\hline Seeking help & .009 & .031 & .022 & .284 & .777 \\
\hline
\end{tabular}

As a part of testing the described prediction model, correlations between predictor variables and academic success were also determined. It turned out that only five (out of 12) predictor variables were in a statistically significant correlation with academic success, and another model of predicting academic success was examined which included only those predictor variables that were in a statistically significant relation to academic success (Table 4) .

Table 4 Prediction of academic success by a reduced number of predictors

\begin{tabular}{|c|c|c|c|c|c|}
\hline \multirow{2}{*}{$\begin{array}{l}\text { Model summary: } \\
\mathrm{R}=.423 ; \mathbf{R}^{2}=. \mathbf{1 7 9} ; \mathrm{F}=8.610 ; \mathbf{p}=\mathbf{. 0 0 0}\end{array}$} & \multicolumn{2}{|c|}{$\begin{array}{l}\text { Unstandardized } \\
\text { Coefficients }\end{array}$} & \multirow{2}{*}{$\begin{array}{c}\begin{array}{c}\text { Standardized } \\
\text { Coefficients }\end{array} \\
\text { Beta } \\
\end{array}$} & \multirow[t]{2}{*}{$\mathrm{t}$} & \multirow[t]{2}{*}{ Sig. } \\
\hline & $\mathrm{B}$ & Std. Error & & & \\
\hline \multicolumn{6}{|l|}{ Attributions to Academic Success } \\
\hline Internal stable & .039 & .035 & .079 & 1.113 & .267 \\
\hline Internal unstable & .046 & .040 & .093 & 1.139 & .256 \\
\hline \multicolumn{6}{|l|}{ Attributions to School Failure } \\
\hline Internal stable & -.093 & .034 & $-.198 * *$ & -2.738 & .007 \\
\hline External unstable & .089 & .032 & $.189 * *$ & 2.787 & .006 \\
\hline \multicolumn{6}{|c|}{ Dealing with the Examination Situation } \\
\hline Focus on the problem & .117 & .046 & $.207 * *$ & 2.566 & .011 \\
\hline
\end{tabular}

This model is also statistically significant and explains a slightly lower percentage of variance in school performance (17.9\%) compared to the previous model. Again, as important particular predictors, focusing on the problem in the testing situation and the external unstable attribution to failure are highlighted, but also a significant contribution of internal stable attributions to failure is now registered (the correlation with academic success is negative here). 
Both tested models confirm the possibility of predicting academic success based on student attributions to academic success and failure and the strategies for dealing with the test situation, and the links of particular predictors with academic success indicate that better success will be achieved by students who are focused on the task in the test situation, as well as those students who interpret failure as accidental and transient, while the interpretation of failure by lack of ability contributes to lower academic success.

The further analysis focuses on examining differences between boys and girls in terms of attributions to academic success and failure, the strategies for dealing with test situations and academic success (Table 5).

Table 5 Differences between boys and girls in the level of expression of examined variables

\begin{tabular}{|c|c|c|c|c|c|c|}
\hline & $\begin{array}{c}\text { Mann- } \\
\text { Whitney U }\end{array}$ & $\begin{array}{c}\text { Wilcoxon } \\
\text { W }\end{array}$ & Z & Sig. & $\begin{array}{l}\text { Males } \\
(\mathrm{N}=67)\end{array}$ & $\begin{array}{l}\text { Females } \\
(\mathrm{N}=137)\end{array}$ \\
\hline \multicolumn{7}{|c|}{ Attributions to Academic Success } \\
\hline Internal stable & 4402.00 & 13588.00 & -0.48 & 0.63 & \multirow{4}{*}{$\begin{array}{c}\text { Mean Rank= } \\
82.19\end{array}$} & \multirow{4}{*}{$\begin{array}{l}\text { Mean Rank= } \\
\mathbf{1 1 2 . 4 3}\end{array}$} \\
\hline Internal unstable & 3299.00 & 5507.00 & -3.47 & 0.01 & & \\
\hline External stable & 4520.00 & 13973.00 & -0.18 & 0.86 & & \\
\hline External unstable & 4450.50 & 6728.50 & -0.35 & 0.72 & & \\
\hline \multicolumn{7}{|c|}{ Attributions to School Failure } \\
\hline Internal stable & 3892.50 & 13345.00 & -1.98 & 0.05 & \multirow[t]{4}{*}{$\begin{array}{c}\text { Mean Rank= } \\
112.90\end{array}$} & \multirow[t]{4}{*}{$\begin{array}{c}\text { Mean Rank= } \\
97.41\end{array}$} \\
\hline Internal unstable & 4568.00 & 6846.00 & -0.05 & 0.96 & & \\
\hline External stable & 4187.00 & 13640.00 & -1.02 & 0.31 & & \\
\hline External unstable & 3890.00 & 6168.00 & -1.77 & 0.07 & & \\
\hline \multicolumn{7}{|c|}{ Dealing with the Examination Situation } \\
\hline Focus on emotions & 3452.00 & 5730.00 & -2.88 & 0.00 & $\begin{array}{c}\text { Mean Rank= } \\
85.52\end{array}$ & \multirow{4}{*}{$\begin{array}{c}\text { Mean Rank= } \\
\mathbf{1 1 0 . 8 0} \\
\text { Mean Rank= } \\
\mathbf{1 1 0 . 4 2}\end{array}$} \\
\hline Focus on the problem & 3504.00 & 5782.00 & -2.72 & 0.01 & $\begin{array}{c}\text { Mean Rank= } \\
86.30\end{array}$ & \\
\hline Fantasy/distraction & 3949.00 & 6227.00 & -1.62 & 0.10 & & \\
\hline Seeking help & 4087.50 & 13540.50 & -1.27 & 0.20 & & \\
\hline Academic Success & 3278.00 & 5556.00 & -3.34 & $\mathbf{0 . 0 0}$ & $\begin{array}{c}\text { Mean Rank= } \\
82.93\end{array}$ & $\begin{array}{c}\text { Mean Rank= } \\
\text { 112.07 }\end{array}$ \\
\hline
\end{tabular}

The analysis shows that girls, compared to boys, tend to attach school achievement to their hard work and dedication. On the other hand, boys, compared with girls, tend to explain school failure with insufficient skills. Regarding the strategies for coping with the test situation, girls are more focused on the problem in the test situation than boys are, as well as on emotions. Finally, the girls from the studied sample achieved higher academic success than the boys.

The last analysis was done to verify that there are specific combinations of particular variables that give a significant contribution to predicting the academic success of boys and girls. Again, prediction models that include all tested variables and then models with fewer variables, have been tested, but now especially on the sub-sample of boys and the sub-sample of girls.

The prediction model that includes all predictor variables on the sub-sample of boys did not reach the level of statistical significance $\left(R=.540, R^{2}=.291, F=1.851, p=.063\right)$, but 
internal stable attributions to failure show a statistically significant Beta coefficient of the negative direction regarding academic success $(\beta=-.618, \mathrm{p}=.004)$. The second prediction model, which includes only variables that are significantly correlated with academic success, carried out on the sub-sample of boys, reached statistical significance $(\mathrm{R}=.499$, $\mathrm{R}^{2}=.249, \mathrm{~F}=4,045, \mathrm{p}=.003$ ), and again the attribution of internal stable causes to failure was a significant individual predictor of academic success $(\beta=-.476, p=.000)$. Based on these results, it can be expected that boys who explain their failure with the lack of ability will achieve lower academic success.

The same prediction models were checked on the sub-sample of girls. Both models are statistically significant (the model that includes all variables: $\mathrm{R}=.508, \mathrm{R}^{2}=.258, \mathrm{~F}=3.593$, $\mathrm{p}=.000$; the model that includes fewer variables: $\mathrm{R}=.469, \mathrm{R}^{2}=.220, \mathrm{~F}=7.396, \mathrm{p}=.000$ ). Particular significant predictors of academic success among the girls are: internal unstable success attributions (in the model that includes all the variables: $\beta=.287, p=.003$; in the model with a reduced number of predictors: $\beta=.255, p=.007$ ), external unstable attribution of failure (in the model that includes all the variables: $\beta=.244, p=.010$; in the model that includes a smaller number of variables: $\beta=.165, \mathrm{p}=.041$ ) and focus on the problem in the test situation (in the model that includes all the variables: $\beta=.198, p=.044$; in the model that includes a smaller number of variables: $\beta=.176, p=.054$ ). Thus, better academic success can be expected among girls who see success as a result of effort, who experience failure as a chance to change (future dedication) and who are focused on the task in the test situation.

\section{DISCUSSION}

The research relies on Weiner's theory of attribution in achievement situations (Weiner 1972, 1985). The existing research findings showing that students' achievements are associated with their attribution styles, which can be functional and dysfunctional, were the starting point (Alloy et al. 1984; Diener and Dweck 1978; Jovanović 2013). Also, the examination situation itself, in which a students' achievement is qualified as success or failure, causes anxiety that may have a disruptive or facilitating effect on a students' performance in this evaluative situation (Mohorić 2008; Živčić-Bećirević 2003). The effect is largely dependent on the strategies a student uses for facing the examination situation (Burić et al. 2011; Živčić-Bećirević 2003).

First of all, the results of this study show that the functional attribution style is the highest expressed attribution style among the students included in the sample. They explain their success to the greatest extent by internal unstable factors, such as invested effort and dedication, and afterwards by internal stable causes (their own abilities). A relatively high score on the dimension of internal stable attributions to success indicates that the examined students believe that they have the skills needed for achieving academic success, but they consider effort and dedication as the most important causes of success. Explaining their success with such attributions, students experience pride, which strengthens their selfesteem and belief in their own abilities (Weiner 1979). Thanks to this, in the next situation they will be ready to engage in solving new challenging and demanding tasks in order to reach higher achievements. When it comes to attributions to failures, students from the sample consider insufficient effort as the main cause of failure. Such attributions to failure arouse self-responsibility and encourage students to invest additional efforts, which leads to desired positive results in the future evaluative situations. On the other hand, students see 
their own abilities as the least responsible for their failure, which has a protective function in relation to their self-esteem, simultaneously preventing the formation of helplessness that could discourage future engagement (Diener and Dweck 1978). The obtained results about the most expressed attributions to success and failure in the studied sample of students are similar to some recent research results (Genet 2016; Sahinkarakas 2011). The results also show that students from the sample use adaptive strategies for coping with the examination situation: they are most focused on the problem (task) and least focused on disturbing thoughts. Considering the average grade that students achieved at the end of the previous school year, which corresponds to excellent academic success, as well as the fact that grammar school students belong to the group of the best students in their generation, these results seem to be consistent.

The tested models of academic success prediction by using the measures of the examined attribution styles and the strategies for dealing with the examination situation confirm the importance of these factors for academic success. Two models have been tested: one that includes all of the examined attribution styles and the strategies for dealing with the examination situation as predictors, and the other that included a smaller number of predictors that were determined by the previous analysis to be in a significant correlation with academic success. In both cases, prediction models were statistically significant and explained a similar percentage of variance (21\% and $17.9 \%$ ) of academic success. In both models, among the examined strategies for dealing with the examination situation, focusing on the problem is the most important particular predictor of academic success. When it comes to attributions, it has been shown that failure attributions are more powerful predictors of academic success than success attributions. Namely, both models of prediction show that students who explain their failure by external unstable causes (current circumstances or luck) achieve better academic success. The model with a smaller number of predictors shows that better success can also be expected in students who are less likely to explain their failure by internal stable causes (abilities). The obtained results are in line with Weiner's attribution theory (Weiner 1972, 1985), with the hypothesis of functional and dysfunctional attribution styles (Alloy et al. 1984), with the description of the behavior of students who, due to dysfunctional failure attributions, develop learned helplessness (Diener and Dweck 1978), with previous findings on the effects of certain attributions styles on students' achievements (Bouchaib, Ahmadou and Abdelkader 2018; Kodzopeljić and Pekić 2017), as well as with the existing findings about the connection of academic success with the strategies for dealing with the examination situation (Cvitković and Wagner-Jakab 2006; Mohorić 2008; Perkun et al. 2002; Živčić-Bećirević 2003).

The analysis of differences between boys and girls showed that the girls from the sample achieved better academic success, and that their attributions and strategies for dealing with the examination situation were more functional than those of the boys. Similar to the findings of some earlier studies (Bugan et al. 2001; Burić et al. 2011; Genet 2016), girls are more focused on the problem in the test situation, and more than boys they tend to interpret their success as a result of effort, while boys are more inclined to explain their failure by lack of ability. This finding not only indicates gender differences, but is also another confirmation of the previously mentioned idea that functional or dysfunctional attribution styles (Jovanović 2013) lead to different cognitive, emotional and behavioral consequences (Kodžopeljić and Pekić 2017) which influence the achievement of academic success. The above-mentioned finding also confirms, just like previous studies (Burić et al. 2011), that test anxiety can have a facilitating effect if students have developed adaptive strategies that involve problem-focused 
behavior. The established differences between boys and girls could be partly explained by specificities in the development of their self-concept, and partly by the differences in education - from their early childhood girls are increasingly encouraged to invest effort, while in the education of boys their abilities are emphasized more. Having in mind the results of the regression analysis which showed that the most important predictors of academic success in girls are functional attributions to success (invested effort and current external circumstances) and focusing on the problem in the examination situation, while among the boys the prediction of academic success is mostly contributed by the degree of dysfunctional failure attributions (lack of ability), it could be said that boys of this age are at a greater risk (than girls) of entering a closed circle going from one failure to the next failure through dysfunctional attributions, learned helplessness, lower self-esteem, a change in learning motivation, avoiding learning and non-adaptive strategies for dealing with the examination situation. Established specific sets of particular predictors of the academic success of boys and girls may, at least partly, explain that, for example, there are twice as many boys than girls among unsuccessful gifted students (Altaras 2006). These findings indicate that boys and girls at adolescent age need somewhat different support in developing functional attribution styles and adaptive strategies for dealing with the examination situation. Particular attention should be paid to encouraging the strategy of focusing on the task in the test situation, and when it comes to attributions, teachers should be especially careful - giving feedback in the failure situation, and not encouraging students to form internal stable attributions. It can be said that the tendency of students to explain their failure by lack of ability presents a kind of risk. Such attributions discourage students from engaging in future situations, thus depriving them of learning opportunities. On the other hand, they influence self-esteem and thus have a negative effect on their overall personal development.

\section{CONCLUSION}

This research has shown that students' attributions to success and failure are important for achieving academic success. Students' attributions in achievement situations determine their future performance (setting goals, perseverance in solving tasks, etc.). Depending on whether students find the causes of their success or failure in external or internal factors, which are more or less controllable, they experience different emotional reactions. The attributions to success and failure, combined with the accompanying emotional reactions, influence students' motivation, expectation of future success, further effort and dedication, self-esteem, the image they have about themselves, and they also determine students' behavior in examination situations.

Despite some limitations of this research that mainly come from the nature and structure of the sample (the convenience sample including only one age group of students who have already been selected by school performance, uneven gender representation), certain practical implications can be derived from it. Bearing in mind that attributions are changeable and that they arise through students' experience of interaction with the school environment, it is clear that teachers have an important role in the process of developing adaptive student attributions, especially in the situation of failure (Demetriou 2011). It means that future teachers' education should be more intensely oriented towards the development of competences needed to understand causal attributions used by students in explaining their own success or failure, as well as competences needed to support students in the formation of functional attribution 
styles (Ilić 2017). In practical work, teachers should help students learn to understand their failures as the consequences of insufficient effort, inadequate strategies for learning and coping with the examination situation, rather than a lack of their abilities. This will contribute to preserving the self-esteem of students and preventing the development of feelings of helplessness. On the other hand, by developing students' tendency to explain their success by invested effort and dedication, as well as by developing the readiness to focus on the problem in the test situation, teachers will contribute to the development of students' responsibility for their own achievements. The most important tool by which teachers can influence the formation of functional students' attributions and adaptive strategies to deal with the examination situation is the feedback they send to students in everyday work. In addition, teachers can encourage students' self-reflection by discussing with them possible reasons for their success or failure. Supporting pupils in developing functional attribution styles and adaptive strategies for coping with the examination situation can be provided through everyday teaching situations, through specially designed workshop activities, through the simulation of test situations and the like. Bearing in mind the findings of this research, it can be said that it is especially important to work on developing functional students' attributions to failure, as well as to train students to focus on the problem in the test situation. As it seems, this kind of support is more necessary for adolescent boys than for girls.

Acknowledgement: The paper is the result of the project Applied Psychology in the Service of the Quality of Life of an Individual in the Community (Faculty of Philosophy, University of Niš, No. 183/1-16-9-01, 28th June 2018).

\section{REFERENCES}

Alloy, Lauren B., Christopher, Peterson, Lyn Y. Abramson, and Martin E. Seligman. "Attributional Style and the Generality of Learned Helplessness". Journal of Personality and Social Psychology 46 (3) (1984): 681687. doi: $10.1037 / 0022-3514.46 .3 .681$

Altaras, Ana. Darovitost i pobacivanje. Pančevo i Beograd: Mali Nemo, Institut za psihologiju i Društvo psihologa Srbije, 2006.

Baucal, Aleksandar, Dragica Pavlović-Babić, Uglješa, Gvozden i Dijana Plut. Obrazovna postignuća učenika trećeg razreda - nacionalno testiranje 2004. Beograd: Ministarstvo prosvete i sporta RS i Zavod za vrednovanje kvaliteta obrazovanja i vaspitanja, 2006.

Birenbaum, Menucha, and Fadia Nasser. "On the Relationship between Test Anxiety and Test Performance". Measurement \& Evaluation in Counseling \& Development 27, 1 (1994): 293-301.

Božin, Aurel. "Školski uspeh kao psihološki problem". Pedagoška stvarnost 49, 5-6 (2003): 499-509.

Bouchaib, Benzehaf, Bouylmani Ahmadou, and Sabil Abdelkader. "High School Students' Attributions of success in English Language Learning". International Journal of Instruction 11 (2) (2018): 89-102. doi: 10.12973/iji.2018.1127a

Bugan, Anita, Martina Bajs, and Zrinka Katarina Stamać. "Kauzalno atribuiranje školskog postignuća srednjoškolaca s obzirom na spol i izraženost motiva za postignućem". Diskrepancija 4 (2001): 51-62.

Burić, Irena, Izabela Sorić, and Zvjezdan Penezić. "Strategije emocionalne regulacije u ispitnim situacijama: doprinosi osobina ličnosti, kognitivnih procjena i ispitnih emocija". Psihologijske teme 20, 2 (2011): 277-298.

Chang, Edward C. "A Look at the Coping Strategies and Styles of Asian Americans: Similar and Different?" In Coping with Stress: Effective People and Processes, edited by Charles R. Snyder, 222-239. New York: Oxford University Press, 2001.

Cvitković, Daniela, and Ana Wagner-Jakab. "Ispitna anksioznost kod djece i mladih s teškoćama učenja". Hrvatska revija za rehabilitacijska istraživanja 2 (2006): 113-126.

Demetriou, Cynthia. "The Attribution Theory of Learning and Advising Students on Academic Probation". NACADA Journal 31, 2 (2011): 16-21. 
Diener, Carol I., and Carol S. Dweck. "An Analysis of Learned Helplessness: Continuous Changes in Performance, Strategy, and Achievement Cognitions following Failure”. Journal of Personality and Social Psychology 36, 5 (1978): 451-462. doi:10.1037/0022-3514.36.5.451

Gadžić, Aleksandar, and Aleksandar Milivojević. "Školski uspeh i status adolescenata u razredu". Teme, 33, 4 (2009): 1379-1389.

Genet, Habtamu. "Causal Attribution of Students to their Academic Achievement". International Journal of Science and Research 51, 3 (2016): 2226-2229.

Gonzalvez, Carolina, Ricardo Sanmartin, Maria Vicent, Candido Ingles, Pilar Aparicio-Flores, and Jose GarciaFernandez. "Academic Self-attributions for Success and Failure in Mathematics and School Refusal". Psychology in the Schools 3 (2018): 1-11. doi: 10.1002/pits.22117

Hamilton, Vernon. "A Cognitive Model of Anxiety - Implications for Theories of Personality and Motivation". Issues in Mental Health Nursing 7, 1-4 (1985): 229-250. doi: 10.3109/01612848509009456

Ilić, Marina. "Pedagoške implikacije Vajnerove atribucione teorije postignuća za inicijalno obrazovanje učitelja". Zbornik radova Pedagoškog fakulteta u Užicu 20, 19 (2017): 21-38.

Jovanović, Olja. "Uticaj implicitnih nastavničkih uverenja na učenje i razvoj učenika". Godišnjak za psihologiju 10 (2013): 55-68.

Kalebić-Maglica, Barbara. "Spolne i dobne razlike adolescenata u suočavanju sa stresom vezanim uz školu". Psihologijske teme 15, 1 (2006): 7-24.

Kodžopeljić, Jasmina i Jasmina Pekić. Psihologija u nastavi: odabrane teme iz psihologije obrazovanja. Novi Sad: Filozofski fakultet, 2017.

Lončarić, Darko. Motivacija i strategije samoregulacije učenja: teorija, mjerenje i primjena. Rijeka: Učiteljski fakultet, 2014

Malle, Bertram F. "Attribution Theories: How People make Sense of Behavior". In Theories in Social Psychology, edited by Derek Chadee, 72-95. Chichester: Wiley-Blackwell, 2011.

McCarthy, Julie M., and Richard D. Goffin. "Selection Test Anxiety: Exploring Tension and Fear of Failure across the Sexes in Simulated Selection Scenarios". International Journal of Selection and Assessment 13, 4 (2005): 282-295. doi: 10.1111/j.1468-2389.2005.00325.x

Mohorić, Tamara. "Automatske misli kod učenja i ispitna anksioznost kao odrednice subjektivnoga i objektivnoga akademskog postignuća studenata". Psihologijske teme 17 (2008): 1-14.

Pekrun, Reinhard, Thomas Goetz, Wolfram Titz, and Raymond Perry. “Academic Eemotions in Student's Selfregulated Learning and Achievement: A Program of Qualitative and Quantitative Research". Educational Psychologist 37, 2 (2002): 91-106. doi: 10.1207/S15326985EP3702 4

Sahinkarakas, Sehnaz. "Young Students' Success and Failure Attributions in Language Learning". Social Behavior and Personality 39, 7 (2011): 879-886. doi: 10.2224/sbp.2011.39.7.879

Schunk, Dale H., Paul R. Pintrich, and Judith L. Meece. Motivation in Education: Theory, Research, and Applications, 4th ed. New Jersey: Pearson Education Inc., 2013.

Sorić, Izabela. "Skale suočavanja s ispitnom situacijom". U Zbirka psihologijskih skala i upitnika, uredile Katica Lacković-Grgin, Ana Proroković, Vera Ćubela i Zvjezdan Penezić, 151-154. Zadar: Filozofski fakultet, 2002.

Stöber, Joachim. "Dimensions of Test Anxiety: Relations to Ways of Coping with Preexam Anxiety and Uncertainty". Anxiety, Stress, and Coping 17, 3 (2004): 213-226. doi: 10.1080/10615800412331292615

Vizek-Vidović, Vlasta, Majda Rijavec, Vesna Vlahović-Štetić, and Dubravka Miljković. Psihologija obrazovanja. Zagreb: IEP-VERN, 2003.

Vulić-Prtorić, Anita i Ivana Lončarević. “Školski uspjeh i mentalno zdravlje”. Napredak 157, 3 (2016): 301-324.

Weiner, Bernard. "Attribution Theory, Achievement Motivation, and the Educational Process". Review of Educational Research 42 (1972): 203-215. doi: 10.3102/00346543042002203

Weiner, Bernard. "A Theory of Motivation for Some Classroom Experiences". Journal of Educational Psychology 71 (1979): 3-25. doi: 10.1037/0022-0663.71.1.3

Weiner, Bernard. “An Attributional Theory of Achievement Motivation and Emotion”. Psychological Review 92 (1985): 548-573. doi: 10.1037/0033-295X.92.4.548

Zeidner. Moshe. "Adaptive Coping with Test Situations: A Review of the Literature”. Educational Psychologist 30, 3 (1995): 123-133. doi: 10.1207/s15326985ep3003_3

Zeidner, Moshe. Test anxiety: The State of the Art. New York: Plenum Press, 1998

Živčić-Bećirević, Ivanka. "Uloga automatskih negativnih misli i ispitne anksioznosti u uspjehu studenata". Društvena istraživanja 5, 67 (2003): 703-720. 


\section{ATRIBUCIJE ŠKOLSKOG USPEHA I NEUSPEHA I STRATEGIJE SUOČAVANJA SA ISPITNOM SITUACIJOM KAO PREDIKTORI ŠKOLSKOG USPEHA}

U istraživanju je ispitivano da li su učeničke atribucije školskog uspeha i neuspeha i strategije suočavanja sa ispitnom situacijom značajni prediktori školskog uspeha. Učeničke atribucije školskog uspeha i neuspeha unutrašnjim i spoljašnjim stabilnim i nestabilnim uzrocima ispitivane su Skalom atribucija školskog uspeha i neuspeha. Strategije suočavanja sa ispitnom situacijom (usmerenost na problem, usmerenost na emocije, maštanje/distrakcija, traženje pomoći u situaciji ispitivanja) ispitivane su Skalom suočavanja sa ispitnom situacijom. Na uzorku učenika drugog razreda gimnazije $(N=204)$ utvrđeno je da učeničke atribucije uspeha/neuspeha i strategije suočavanja sa ispitnom situacijom objašnjavaju značajan procenat varijanse školskog uspeha $\left(R^{2}=.210, p=.000\right)$. Najznačajniji pojedinačni prediktor je strategija usmeravanja na problem u ispitnoj situaciji ( $\beta=.244, p=.005)$. Učeničke atribucije neuspeha su značajniji prediktori školskog uspeha nego atribucije uspeha. Utvrđene su $i$ razlike $u$ značaju pojedinačnih prediktora za predviđanje školskog uspeha dečaka $i$ devojčica. Rezultati ukazuju na značaj podsticanja konstruktivnih učeničkih atribucija uspeha/neuspeha i strategija suočavanja sa ispitnom situacijom.

Ključne reči: učenici, školski uspeh, učeničke atribucije uspeha i neuspeha, suočavanje sa ispitnom situacijom 